\title{
Article \\ Comparative Analysis of the Filling Capacity of Simulated Lateral Canals of Two Bioactive Root Canal Sealers Using Warm Gutta-Percha Technique
}

\author{
Jesús Mena-Álvarez *(D), Juliette Theophanie Sevrain, Mario Zorita-García and Cristina Rico-Romano \\ Department of Endodontics, Faculty of Dentistry, Alfonso X El Sabio University, \\ 28691 Villanueva de la Cañada, Madrid, Spain; julsevrain@msn.com (J.T.S.); marriete11@hotmail.com (M.Z.-G.); \\ cromaric@uax.es (C.R.-R.) \\ * Correspondence: jmenaalv@uax.es
}

Citation: Mena-Álvarez, J.; Sevrain, J.T.; Zorita-García, M.; Rico-Romano, C. Comparative Analysis of the Filling Capacity of Simulated Lateral Canals of Two Bioactive Root Canal Sealers Using Warm Gutta-Percha Technique. Appl. Sci. 2021, 11, 6270. https://doi.org/10.3390/app11146270

Academic Editor: Paola Gandini

Received: 16 June 2021

Accepted: 5 July 2021

Published: 7 July 2021

Publisher's Note: MDPI stays neutral with regard to jurisdictional claims in published maps and institutional affiliations.

Copyright: (c) 2021 by the authors. Licensee MDPI, Basel, Switzerland. This article is an open access article distributed under the terms and conditions of the Creative Commons Attribution (CC BY) license (https:/ / creativecommons.org/licenses/by/ $4.0 /)$.

\begin{abstract}
The aim of this study was to evaluate ex vivo the sealing achieved at simulated lateral canals (SLC) and the quality of filling according to their position in the root canal after using the same filling technique. SLC were created at three levels in 55 teeth and divided into two groups depending on the root canal sealer used (1: BioRoot ${ }^{\circledR}$ RCS, 2: GuttaFlow ${ }^{\circledR}$ bioseal). They filled them with the continuous wave technique and submitted to a diaphanization technique. The samples were analyzed using a magnifying lens $(20 \times)$, pictures were taken, which proceeded to linear measurement with the Image ${ }^{\circledR}$ program and used a filling score system with five grades ( 0 to 4,0 and 1 not acceptable, 2 to 4 acceptable); BioRoot ${ }^{\circledR}$ RCS has got a greater proportion than GuttaFlow ${ }^{\circledR}$ bioseal for SLC filled acceptably at $10 \mathrm{~mm}$ from the apex $(p<0.05)$. The highest proportion of SLC filled acceptably was found in the middle third $(6 \mathrm{~mm})(p<0.05)$, followed by the apical third $(3 \mathrm{~mm})$ and the coronal third $(10 \mathrm{~mm})$. The difference between apical and coronal third could be significant; BioRoot ${ }^{\circledR}$ RCS has been better than GuttaFlow ${ }^{\circledR}$ bioseal for filling SLC in the coronal third of the teeth. Studies on the characteristics of these cements are missing to explain these differences.
\end{abstract}

Keywords: bioceramics; root canal sealers; simulated lateral canals; warm obturation; extrusion

\section{Introduction}

Endodontic obturation is an essential step in endodontic treatment; it is aimed at sealing the root canal system, preventing future bacterial contamination or recontamination [1]. For the success of endodontic treatment, it is important to achieve a filling that fully occupies the anatomy of the instrumented root canal. In this sense, the obturation of the lateral and/or accessory canals could play a significant role [2]. The presence of lateral canals represents a two-way path between the root canal and the periradicular tissues, which facilitates the passage of bacteria and their products [3]. Lateral canals are formed by the entrapment of periodontal vessels in Hertwig's epithelial sheath during root calcification [4].

The root canal system presents a complex anatomy, in which a significant percentage of lateral and/or accessory canals are observed, distributed according to the different root zones. De Deus et al. [5] found $27.4 \%$ of lateral canals with a distribution of $17 \%$ in the apical third, $8.8 \%$ in the middle and $1.6 \%$ in the coronary.

The most common root canal obturating material is gutta-percha (GP), used in conjunction with various sealers. Different bioactive root canal sealers with regenerative properties have been introduced to the market. GuttaFlow ${ }^{\circledR}$ bioseal (GFB) (Coltène/Whaledent $\mathrm{GmbH}$, Altstätten, Switzerland) is composed of gutta-percha powder, polydimethylsiloxane, platinum catalyst, zirconium dioxide, and bioactive glass ceramic. GFB was developed to improve the bioactivity of GuttaFlow ${ }^{\circledR}$, favoring the regeneration of the apical tissues [6]. GFB is a hydrophilic sealant that has shown low solubility and porosity, alkalizing ability, and penetrability of dentin [7] being also cytocompatibility [8]. According 
to Tanomaru et al. [9], GFB has physicochemical properties appropriate to ISO and ADA (American Dental Association) standards, in terms of setting time, radiopacity, solubility at 7 and 30 days, and fluidity and volumetric change at 7 and 30 days. According to Gandolfi et al. [10], GuttaFlow ${ }^{\circledR}$ bioseal proved to be a promising endodontic material used in teeth with a broad (apical diameter 40) and wet apex, thanks to the incorporation of a calcium silicate component. However, the low calcium release evaluated limits its adoption in conditions in which an apical barrier formation is required.

Bioceramics used in endodontics can be categorized by composition, setting mechanism, and consistency, and they are all hydrophilic. Bioceramic sealers have remarkable properties in terms of biocompatibility and antimicrobial activity with excellent bioactivity, capable of inducing mineralization of the periapical tissues [11-13]. Due to their hydrophilicity, they can set in a humid environment such as dentin, which is made up of almost 20\% water [14]. BioRoot ${ }^{\circledR}$ RCS (Septodont, Saint Maur-des-Fosses, France) is an endodontic sealer with tricalcium silicate materials that benefit from the Active Biosilicate Technology and Biodentine ${ }^{\circledR}$ platform. Thanks to the use of Active BioSilicate technology, which is free of monomers, there is no shrinkage of BioRoot ${ }^{\circledR}$ RCS during setting to allow a high root canal seal. BioRoot ${ }^{\circledR}$ RCS is bioactive by stimulating the physiological formation of bone and mineralization of the dentin structure $[15,16]$. Thus, it creates a favorable environment for periapical healing and bioactive properties including biocompatibility [17], hydroxyapatite formation, mineralization of the dentin structure, alkaline $\mathrm{pH}$ [18], and sealing properties. BioRoot ${ }^{\circledR}$ RCS is indicated for permanent root canal filling in combination with gutta-percha points and is suitable for use in single taper or cold lateral condensation techniques [19]. The use of bioceramic sealers is associated with single-cone filling techniques and not with vertical condensation with continuous wave, because heat interferes with their characteristics. Some authors have observed that gutta-percha thermoplastification affects the total obturation volume, creating fewer voids and gaps [20-22]. However, Somma et al. and Celikten et al. compared different techniques using the $\mathrm{AH}$ Plus and EndoSequence sealers, respectively, and did not observe an influence of technique on obturation quality, regardless of the thermoplastification $[23,24]$.

The teeth clearing technique is a useful method for obtaining information on root canal systems and for evaluating endodontic fillings [25], although today there are other techniques that allow us to make more precise simulations, such as micro-Ct analysis [26] and finite element analysis (FEA); however, there is varying reliability of FEA reported in literature [27].

In this context, the aim of this work was to evaluate ex vivo the three-dimensional sealing achieved at the level of the simulated lateral canals (SLC) after the use of different endodontic sealers that incorporate nanoparticle technologies with the same endodontic obturation technique (vertical condensation with continuous wave followed by injection of thermoplasticized gutta-percha).

\section{Materials and Methods}

This study was approved by the Research Ethics Committee of Alfonso X El Sabio University. All patients gave their informed consent to transfer teeth for the study. The sample size was determined based on the study of Fernández et al. [28] with statistical significance. It assumes that this study will have an alpha risk (significance 5\%) with a beta risk (potency $80 \%$ ), in such a way that Group 1 will have an estimated proportion of $30 \%$ and Group 2 will have an estimated proportion of $70 \%$; therefore, 24 items would be needed for each group.

A total of 55 recently extracted teeth (upper and lower incisors and premolars) with intact roots and mature apices were collected from the Oral Surgery Department of the University and stored at 100\% humidity. The teeth were washed under tap water immediately after extraction and stored in distilled water with thymol iodide crystals (Braun ${ }^{\circledR}$, Melsungen, Germany) until the collection was complete (1 month maximum). After this, 
the samples were washed thoroughly under tap water and immersed in $2.5 \%$ sodium hypochlorite for $30 \mathrm{~min}$ to remove adherent soft tissue.

We made the following groups: (1) BioRoot ${ }^{\circledR}$ RCS $(n=25)$; (2) GuttaFlow ${ }^{\circledR}$ bioseal $(\mathrm{n}=25)$; (3) Control Group filled without cement $(\mathrm{n}=5)$. Teeth were randomized into two groups with EPIDAT 3.1 (Dirección Xéral de Saude Pública, Galicia, Spain), and a control group of five teeth (Table 1).

Table 1. The composition of the cement sealers.

\begin{tabular}{ccc}
\hline Materials & Manufacturer & Composition \\
Guttaflow Bioseal & $\begin{array}{c}\text { Coltène/Whaledent, } \\
\text { Altstätten, Switzerland }\end{array}$ & $\begin{array}{c}\text { Gutta-percha powder particles, } \\
\text { polydimethylsiloxane, platinum catalysis, } \\
\text { zirconium dioxide, calcium salicylate, bioactive } \\
\text { glass ceramic, color pigments, nano silver } \\
\text { particles, silicates, silicone oils, zinc oxide. } \\
\text { BioRoot RCS }\end{array}$ \\
& $\begin{array}{c}\text { Septodont, Saint } \\
\text { Maur-des-Fosses, } \\
\text { France }\end{array}$ & $\begin{array}{c}\text { Power: tricalcium silicate, zirconium oxide and } \\
\text { povidone. Liquid: water, calcium chloride } \\
\text { and polycarboxylate. }\end{array}$ \\
\hline
\end{tabular}

After cleaning their root surface with ultrasound, the teeth were placed in $5 \%$ sodium hypochlorite for one hour and subsequently stored in $0.9 \%$ saline until their preparation [28]. The teeth were instrumented up to R25 from the Reciproc ${ }^{\circledR}$ (VDW, Munich, Germany) file system, with the Silver Reciproc ${ }^{\circledR}$ engine (VDW, Munich, Germany). Once the instrumentation was finished, $5.25 \%$ sodium hypochlorite (Clorox, Oakland, CA, USA) was activated using sonic activation with EndoActivator ${ }^{\circledR}$ (DentsplySirona Endodontics, Ballaigues, Switzerland) for $1 \mathrm{~min}$, with $5 \mathrm{~mL}$ in each canal. An endodontic needle (Miraject Endo Luer ${ }^{\circledR}$, Hager and Werken, Duisburg, Germany) was brought to $1 \mathrm{~mm}$ from working length [29]. Then, irrigation with $5 \mathrm{~mL}$ of $17 \%$ EDTA (SmearClear ${ }^{\circledR}$, SybronEndo, Orange, CA, USA) was carried out to eliminate the smear layer and, finally, they were irrigated with sodium hypochlorite [30].

After completing the instrumentation and cleaning process, the teeth were decalcified using the Robertson and Leeb technique [31]. The teeth were immersed in 5\% nitric acid for $36 \mathrm{~h}$, changing it every $8 \mathrm{~h}$, and shaking manually 3 times a day [32,33]. Once decalcified, the teeth had a rubbery consistency and were flexible. They were rinsed in distilled water for $3 \mathrm{~min}$ and simulated lateral canals (SLC) were created at 3, 6 and $10 \mathrm{~mm}$ from the working length [28], introducing a \#10 K-file, perpendicular to the external surface. A total of 6 canals were simulated for each tooth [34]. Vertical heat condensation with a continuous wave was used for the filling in all cases (Elements ${ }^{\circledR}$, Sybron Endo, Orange, CA, USA), and the root canal sealers used were varied. To simulate the periodontal ligament, the roots were covered by a sheet of foam rubber and wrapped with Teflon tape [35]. A calibrated $\mathrm{R} 25^{\circledR}$ cone (VDW, Munich, Germany) was selected to have tug-back at working length (WL). It was covered with cement in its last $5 \mathrm{~mm}$ and inserted into the canal until reaching WL. Injected gutta-percha was used for the obturation of the middle and coronal thirds.

According to Robertson and Leeb [31], the samples were dehydrated in $80 \%$ ethyl alcohol for eight hours, $90 \%$ for one hour, and $100 \%$ for three hours, changing the alcohol every hour to be subsequently immersed in $99.9 \%$ methyl salicylate to transparentize and re-harden the dental tissues. The teeth were photographed immersed in methyl salicylate. Photographs were analyzed using the Image ${ }^{\circledR}$ (National Institutes of Health, Bethesda, MD, USA) software where lines were drawn and obtained a numerical measurement. From this measurement, the percentage of obstruction of the lateral canal was calculated. According to radiography, the extrusion through the apex of the filling material was observed:

$0=$ No extrusion

$1=$ There is extrusion. 
According to the microscope images by visual inspection of the samples and analysis of the photographs with the Image ${ }^{\circledR}$ program, apical branches revealed by the obturation were observed:

$0=$ no branching

$1=$ apical branching.

The scoring system described by Fernandez et al., according to Venturi et al. [25,28] was used. All accessory canals were observed on four surfaces (mesial, buccal, distal and palatal) with increasing magnifications. Five scores were defined to evaluate the filling of accessory channels: $0=$ no filling (grade 0 ), filling with cement only $<10 \%$ of its total length; 1 = partial filling with cement without gutta-percha (grade 1), filling with cement not up to its full length, or not three-dimensionally, so the empty spaces were identifiable; 2 = complete filling with cement without gutta-percha (grade 2), three-dimensional filling and up to its total length with cement, without the presence of gutta-percha, or with gutta-percha up to $50 \%$ of its total length; $3=$ complete filling with cement and partial filling with gutta-percha (grade 3), three-dimensional filling to its full length by cement in which the gutta-percha penetrated 50 to $90 \%$ of its total length. However, the space not filled by gutta-percha was completely filled with cement; and $4=$ complete filling with cement and gutta-percha (grade 4), completely filled with cement and gutta-percha.

The partially or unfilled canals, scores 0 and 1, were categorized as not acceptable, while scores 2 to 4 were considered acceptable: $0=$ not acceptable, grades 0 and $1 ; 1=$ acceptable, grades $2-4$

\section{Results}

Of the total of the SLC, 25\% have been filled in an Acceptable way (grades 2 to 4 ) and cement extrusion was found in $10.4 \%$ of the studied teeth. Apical ramifications revealed by the filling and filled with cement were found in $18.75 \%$ of the studied teeth.

Figure 1 shows the proportion of canal filling according to the filling depth, regardless of the type of cement. The highest proportion of acceptably filled canals (grades 2 to 4 ) was found in the middle third (canal $6 \mathrm{~mm}$ from the apex), followed by the apical third ( $3 \mathrm{~mm}$ ) and then the coronal third $(10 \mathrm{~mm})$.

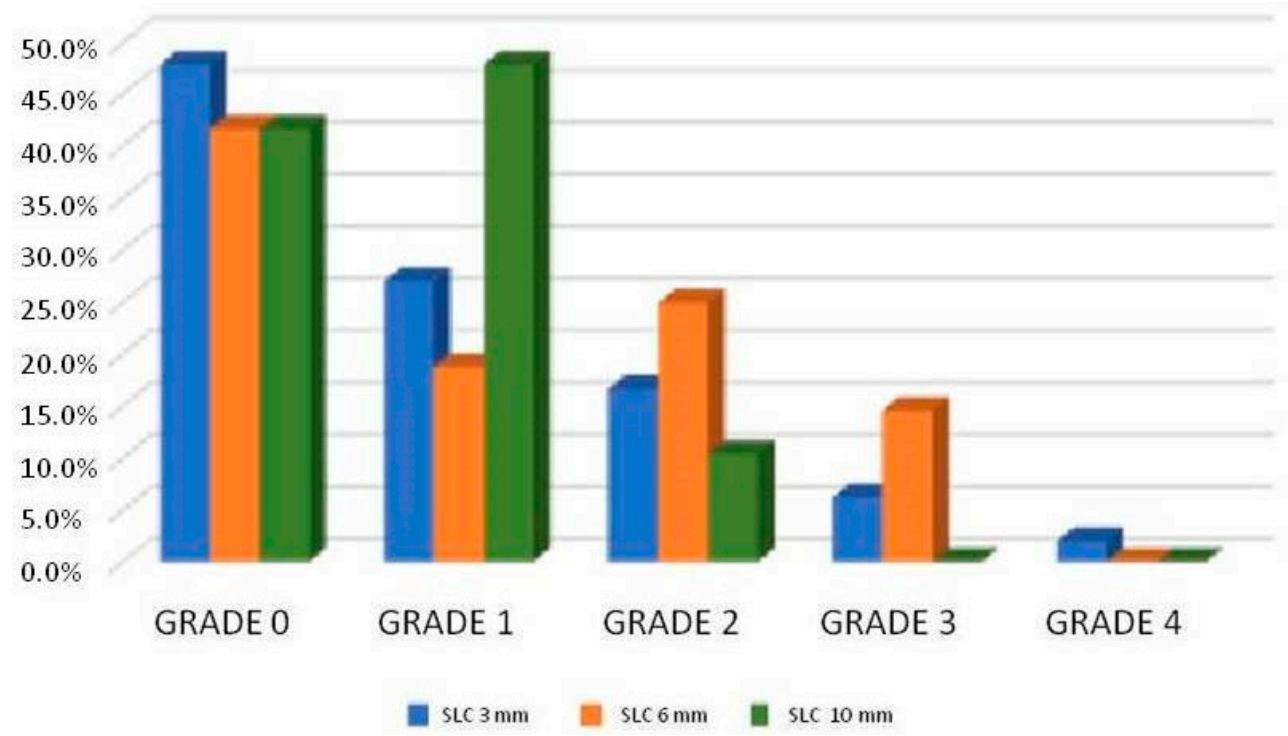

Figure 1. Degree of obturation according to the third studied.

Table 2 shows the results in the lateral canals at $3 \mathrm{~mm}$ of the apex between the sealer groups where there were statistically significant differences between sealers: BioRoot ${ }^{\circledR}$ RCS has allowed more grade 2 fillings $(33.3 \%)$ in the $3 \mathrm{~mm}$ SLC than GuttaFlow ${ }^{\circledR}$ bioseal $(4.5 \%)$, 
and it was statistically significant $(p$-value $<0.05)$. Among the rest of the sealers and grades, the differences were not significant.

Table 2. Filling values of CLS at $3 \mathrm{~mm}$ according to the type of root canal sealer.

\begin{tabular}{|c|c|c|c|c|c|c|}
\hline & & & \multicolumn{3}{|c|}{ Root Canal Sealer } & \multirow[b]{2}{*}{ Total } \\
\hline & & & None & $\begin{array}{c}\text { Biorrot } \\
\text { RCS }\end{array}$ & $\begin{array}{c}\text { GutaFlow } \\
\text { Bioseal }\end{array}$ & \\
\hline \multirow{10}{*}{ At $3 \mathrm{~mm}$} & \multirow{2}{*}{ Grade 0} & Count & 5 & 9 & 9 & 23 \\
\hline & & $\%$ within root canal sealer used & 100 & 42.9 & 40.9 & 47.9 \\
\hline & \multirow[b]{2}{*}{ Grade 1} & Count & 0 & 5 & 8 & 13 \\
\hline & & $\%$ within root canal sealer used & 0 & 23.8 & 36.4 & 27.1 \\
\hline & \multirow{2}{*}{ Grade 2} & Count & 0 & 7 & 1 & 8 \\
\hline & & $\%$ within root canal sealer used & 0 & 33.3 & 4.5 & 16.7 \\
\hline & \multirow{2}{*}{ Grade 3} & Count & 0 & 0 & 3 & 3 \\
\hline & & $\%$ within root canal sealer used & 0 & 0 & 13.6 & 6.3 \\
\hline & \multirow{2}{*}{ Grade 4} & Count & 0 & 0 & 1 & 1 \\
\hline & & $\%$ within root canal sealer used & 0 & 0 & 4.5 & 2.1 \\
\hline \multirow{2}{*}{\multicolumn{2}{|c|}{ TOTAL }} & Count & 5 & 21 & 22 & 48 \\
\hline & & $\%$ within root canal sealer used & 100 & 100 & 100 & 100 \\
\hline
\end{tabular}

Table 3 shows the results in the lateral canals at $6 \mathrm{~mm}$ of the apex between the sealer groups, and there were differences between sealers: GuttaFlow ${ }^{\circledR}$ bioseal has allowed more grade 3 fillings $(27.3 \%)$ in the $6 \mathrm{~mm}$ SLC than BioRoot ${ }^{\circledR}$ RCS (4.8\%), and it was statistically significant $(p$-value $<0.05)$. Among the rest of the root canal sealers and grades, the differences there were not significant.

Table 3. Filling values of CLS at $6 \mathrm{~mm}$ according to the type of root canal sealer.

\begin{tabular}{|c|c|c|c|c|c|c|}
\hline & & & \multicolumn{3}{|c|}{ Root Canal Sealer } & \multirow[b]{2}{*}{ Total } \\
\hline & & & None & $\begin{array}{c}\text { Biorrot } \\
\text { RCS }\end{array}$ & $\begin{array}{c}\text { GutaFlow } \\
\text { Bioseal }\end{array}$ & \\
\hline \multirow{8}{*}{ At $6 \mathrm{~mm}$} & \multirow{2}{*}{ Grade 0} & Count & 5 & 9 & 6 & 20 \\
\hline & & $\%$ within root canal sealer used & 100 & 42.9 & 27.3 & 41.7 \\
\hline & \multirow[b]{2}{*}{ Grade 1} & Count & 0 & 3 & 6 & 9 \\
\hline & & $\%$ within root canal sealer used & 0 & 14.3 & 27.3 & 18.8 \\
\hline & \multirow{2}{*}{ Grade 2} & Count & 0 & 8 & 4 & 12 \\
\hline & & $\%$ within root canal sealer used & 0 & 38.1 & 18.2 & 25 \\
\hline & \multirow{2}{*}{ Grade 3} & Count & 0 & 1 & 6 & 7 \\
\hline & & $\%$ within root canal sealer used & 0 & 4.8 & 27.3 & 14.6 \\
\hline \multirow{2}{*}{\multicolumn{2}{|c|}{ TOTAL }} & Count & 5 & 21 & 22 & 48 \\
\hline & & $\%$ within root canal sealer used & 100 & 100 & 100 & 100 \\
\hline
\end{tabular}

Table 4 shows the results in the lateral canals at $10 \mathrm{~mm}$ of the apex between the sealer groups, and there were differences between cements: BioRoot ${ }^{\circledR}$ RCS has allowed more grade 2 fillings $(23.8 \%)$ of SLC at $10 \mathrm{~mm}$ than GuttaFlow ${ }^{\circledR}$ bioseal $(0 \%)$ and was statistically significant $(p$-value $<0.05)$. Among the rest of the sealers and grades, the differences were not significant. 
Table 4. Filling values of CLS at $10 \mathrm{~mm}$ according to the type of root canal sealer.

\begin{tabular}{|c|c|c|c|c|c|c|}
\hline & & & \multicolumn{3}{|c|}{ Root Canal Sealer } & \multirow[b]{2}{*}{ Total } \\
\hline & & & None & $\begin{array}{c}\text { Biorrot } \\
\text { RCS }\end{array}$ & $\begin{array}{c}\text { GutaFlow } \\
\text { Bioseal }\end{array}$ & \\
\hline \multirow{6}{*}{ At $10 \mathrm{~mm}$} & \multirow{2}{*}{ Grade 0} & Count & 5 & 7 & 8 & 20 \\
\hline & & $\%$ within root canal sealer used & 100 & 33.3 & 36.4 & 41.7 \\
\hline & \multirow{2}{*}{ Grade 1} & Count & 0 & 9 & 14 & 23 \\
\hline & & $\%$ within root canal sealer used & 0 & 42,9 & 63,6 & 47,9 \\
\hline & \multirow{2}{*}{ Grade 2} & Count & 0 & 5 & 0 & 5 \\
\hline & & $\%$ within root canal sealer used & 0 & 23,8 & 0 & 10,4 \\
\hline \multirow{2}{*}{\multicolumn{2}{|c|}{ TOTAL }} & Count & 5 & 21 & 22 & 48 \\
\hline & & $\%$ within root canal sealer used & 100 & 100 & 100 & 100 \\
\hline
\end{tabular}

Table 5 and Figure 2 show the satisfaction values in the root canal sealer groups at $3 \mathrm{~mm}$. For SLC acceptably filled $3 \mathrm{~mm}$ from the apex, BioRoot ${ }^{\circledR}$ RCS has obtained the highest ratio. However, the difference was not statistically significant ( $p$-value $>0.05$ ).

Table 5. Satisfaction of filling in SLC at $3 \mathrm{~mm}$ in each root canal sealer.

\begin{tabular}{|c|c|c|c|c|c|c|}
\hline & & & \multicolumn{3}{|c|}{ Root Canal Sealer } & \multirow[b]{2}{*}{ Total } \\
\hline & & & None & $\begin{array}{l}\text { Biorrot } \\
\text { RCS }\end{array}$ & $\begin{array}{l}\text { GutaFlow } \\
\text { Bioseal }\end{array}$ & \\
\hline \multirow{4}{*}{$\begin{array}{l}\text { SLC satisfaction } \\
\qquad 3 \mathrm{~mm}\end{array}$} & No acceptable. Grade 0 & Count & 5 & 14 & 17 & 36 \\
\hline & and 1 & $\%$ within root canal sealer used & 100 & 66.7 & 77.3 & 75 \\
\hline & Acceptable. Grade 2, 3 & Count & 0 & 7 & 5 & 12 \\
\hline & y 4 & $\%$ within root canal sealer used & 0 & 33.3 & 22.7 & 25 \\
\hline \multirow{2}{*}{\multicolumn{2}{|c|}{ TOTAL }} & Count & 5 & 21 & 22 & 48 \\
\hline & & $\%$ within root canal sealer used & 100 & 100 & 100 & 100 \\
\hline
\end{tabular}

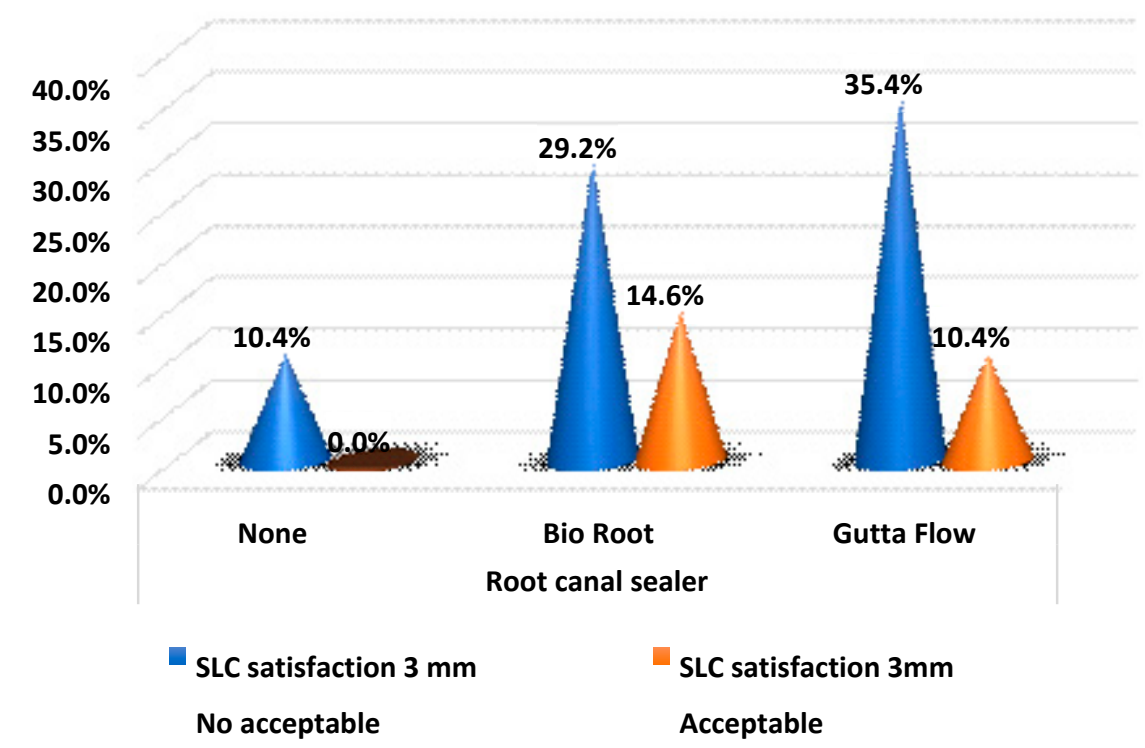

Figure 2. Satisfaction of filling in SLC at $3 \mathrm{~mm}$ in each root canal sealer. Bar chart.

Table 6 and Figure 3 show the satisfaction values in the sealer groups at $6 \mathrm{~mm}$. GuttaFlow $^{\circledR}$ bioseal had a higher proportion of acceptable fillers, but the difference was not statistically significant ( $p$-value $>0.05$ ). 
Table 6. Satisfaction of filling in SLC at $6 \mathrm{~mm}$ in each root canal sealer.

\begin{tabular}{|c|c|c|c|c|c|c|}
\hline & & & \multicolumn{3}{|c|}{ Root Canal Sealer } & \multirow[b]{2}{*}{ Total } \\
\hline & & & None & $\begin{array}{c}\text { Biorrot } \\
\text { RCS }\end{array}$ & $\begin{array}{c}\text { GutaFlow } \\
\text { Bioseal }\end{array}$ & \\
\hline \multirow{4}{*}{$\begin{array}{l}\text { SLC satisfaction } \\
6 \mathrm{~mm}\end{array}$} & No acceptable. Grade 0 & Count & 5 & 12 & 12 & 29 \\
\hline & and 1 & $\%$ within root canal sealer used & 100 & 57.1 & 54.5 & 60.4 \\
\hline & Acceptable. Grade 2, 3 & Count & 0 & 9 & 10 & 19 \\
\hline & y 4 & $\%$ within root canal sealer used & 0 & 42.9 & 45.5 & 39.6 \\
\hline \multirow{2}{*}{\multicolumn{2}{|c|}{ TOTAL }} & Count & 5 & 21 & 22 & 48 \\
\hline & & $\%$ within root canal sealer used & 100 & 100 & 100 & 100 \\
\hline
\end{tabular}

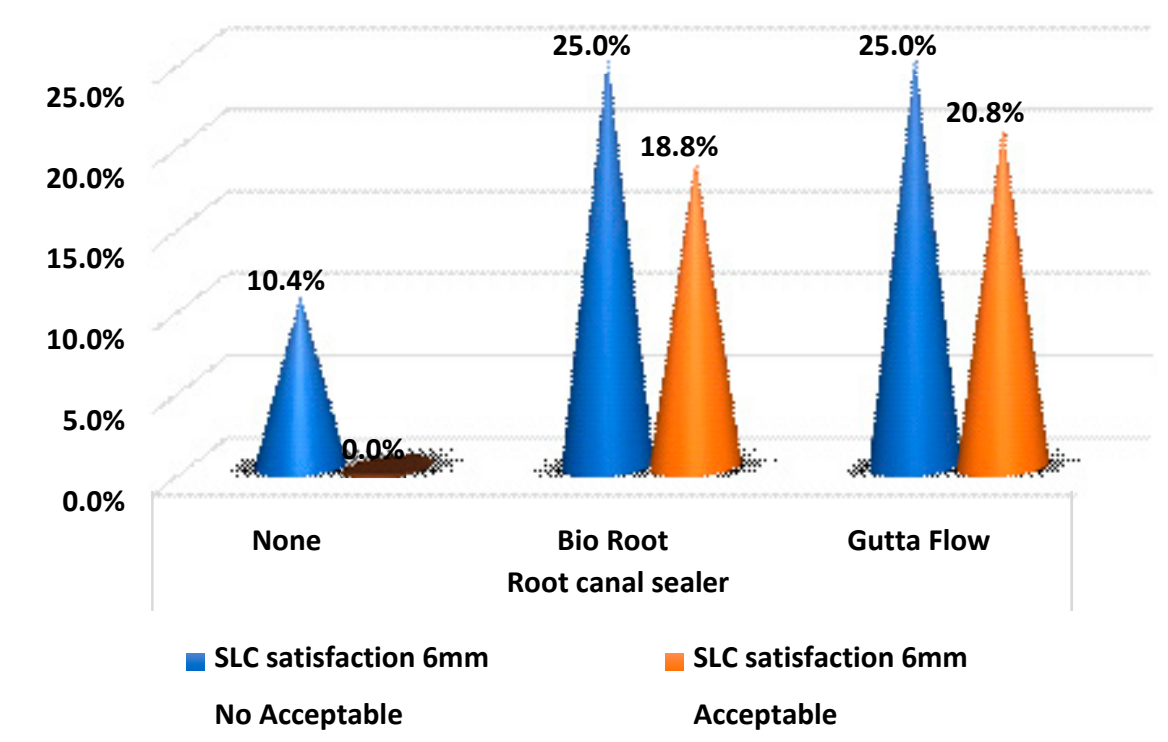

Figure 3. Satisfaction of filling in SLC at $6 \mathrm{~mm}$ in each root canal sealer. Bar chart.

Table 7 and Figure 4 show the satisfaction values in the sealer groups at $10 \mathrm{~mm}$. BioRoot $^{\circledR}$ RCS had a higher proportion than GuttaFlow ${ }^{\circledR}$ bioseal, and it was statistically significant ( $p$-value $<0.05)$.

Table 7. Satisfaction of filling in SLC at $10 \mathrm{~mm}$ in each root canal sealer.

\begin{tabular}{|c|c|c|c|c|c|c|}
\hline & & & \multicolumn{3}{|c|}{ Root Canal Sealer } & \multirow[b]{2}{*}{ Total } \\
\hline & & & None & $\begin{array}{l}\text { Biorrot } \\
\text { RCS }\end{array}$ & $\begin{array}{l}\text { GutaFlow } \\
\text { Bioseal }\end{array}$ & \\
\hline \multirow{4}{*}{$\begin{array}{l}\text { SLC satisfaction } \\
\qquad 10 \mathrm{~mm}\end{array}$} & No acceptable. Grade 0 & Count & 5 & 16 & 22 & 43 \\
\hline & and 1 & $\%$ within root canal sealer used & 100 & 76.2 & 100 & 89.6 \\
\hline & Acceptable. Grade 2, 3 & Count & 0 & 5 & 0 & 5 \\
\hline & y 4 & $\%$ within root canal sealer used & 0 & 23.8 & 0 & 10.4 \\
\hline \multirow{2}{*}{\multicolumn{2}{|c|}{ TOTAL }} & Count & 5 & 21 & 22 & 48 \\
\hline & & $\%$ within root canal sealer used & 100 & 100 & 100 & 100 \\
\hline
\end{tabular}




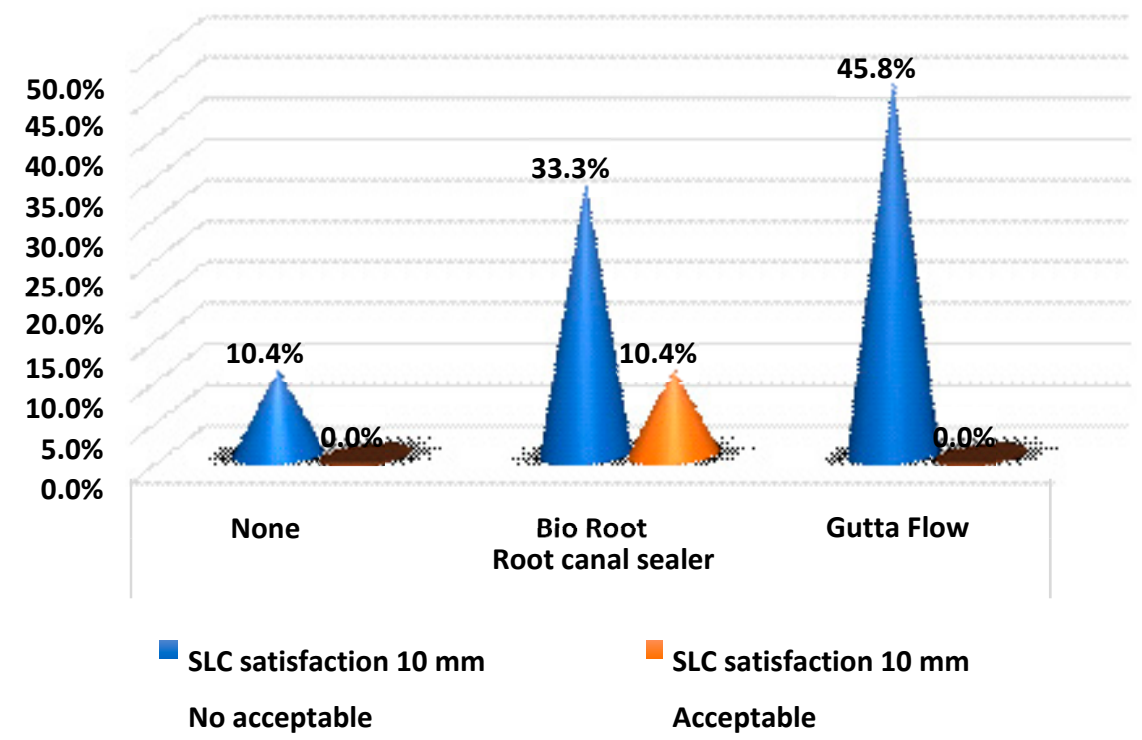

Figure 4. Satisfaction of filling in SLC at $10 \mathrm{~mm}$ in each root canal sealer. Bar chart.

Regarding cement extrusion, there were no significant differences according to the type of root canal sealer, and the extrusion ratio was the same between the two groups (Table 8 and Figure 5).

Table 8. Extrusion ratio in each root canal sealer group.

\begin{tabular}{|c|c|c|c|c|c|c|}
\hline & & & \multicolumn{3}{|c|}{ Root Canal Sealer } & \multirow[b]{2}{*}{ Total } \\
\hline & & & None & $\begin{array}{c}\text { Biorrot } \\
\text { RCS }\end{array}$ & $\begin{array}{c}\text { GutaFlow } \\
\text { Bioseal }\end{array}$ & \\
\hline \multirow{4}{*}{$\begin{array}{l}\text { Apical extrusion root- } \\
\text { canal sealer }\end{array}$} & \multirow{2}{*}{ NO extrusion } & Count & 5 & 19 & 19 & 43 \\
\hline & & $\%$ within root canal sealer used & 100 & 90.5 & 86.4 & 89.6 \\
\hline & \multirow{2}{*}{ Extrusion } & Count & 0 & 2 & 3 & 5 \\
\hline & & $\%$ within root canal sealer used & 0 & 9.5 & 3.6 & 10.4 \\
\hline \multirow{2}{*}{\multicolumn{2}{|c|}{ TOTAL }} & Count & 5 & 21 & 22 & 48 \\
\hline & & $\%$ within root canal sealer used & 100 & 100 & 100 & 100 \\
\hline
\end{tabular}

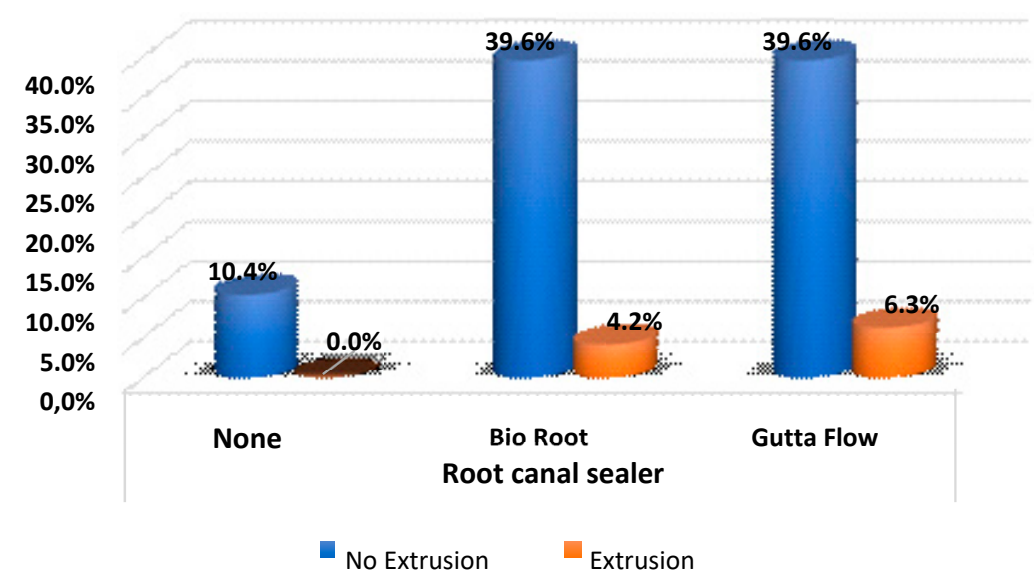

Figure 5. Extrusion ratio in each root canal sealer group. Bar chart.

Finally, there were no significant differences in the branches according to the type of sealer ( $p$-value $>0.05$ ) The proportion of apical ramifications revealed by the filling were similar between the two sealers without significant differences (Table 9 and Figure 6). 
Table 9. Proportion of apical branches in each root canal sealer group.

\begin{tabular}{|c|c|c|c|c|c|c|}
\hline & & & \multicolumn{3}{|c|}{ Root Canal Sealer } & \multirow[b]{2}{*}{ Total } \\
\hline & & & None & $\begin{array}{l}\text { Biorrot } \\
\text { RCS }\end{array}$ & $\begin{array}{c}\text { GutaFlow } \\
\text { Bioseal }\end{array}$ & \\
\hline \multirow{4}{*}{ Apical branching } & No apical & Count & 5 & 18 & 16 & 39 \\
\hline & branching & $\%$ within root canal sealer used & 100 & 85.7 & 72.7 & 81.3 \\
\hline & Anical branching & Count & 0 & 3 & 6 & 9 \\
\hline & Apical brancning & $\%$ within root canal sealer used & 0 & 14.3 & 27.3 & 18.8 \\
\hline \multirow{2}{*}{\multicolumn{2}{|c|}{ TOTAL }} & Count & 5 & 21 & 22 & 48 \\
\hline & & $\%$ within root canal sealer used & 100 & 100 & 100 & 100 \\
\hline
\end{tabular}

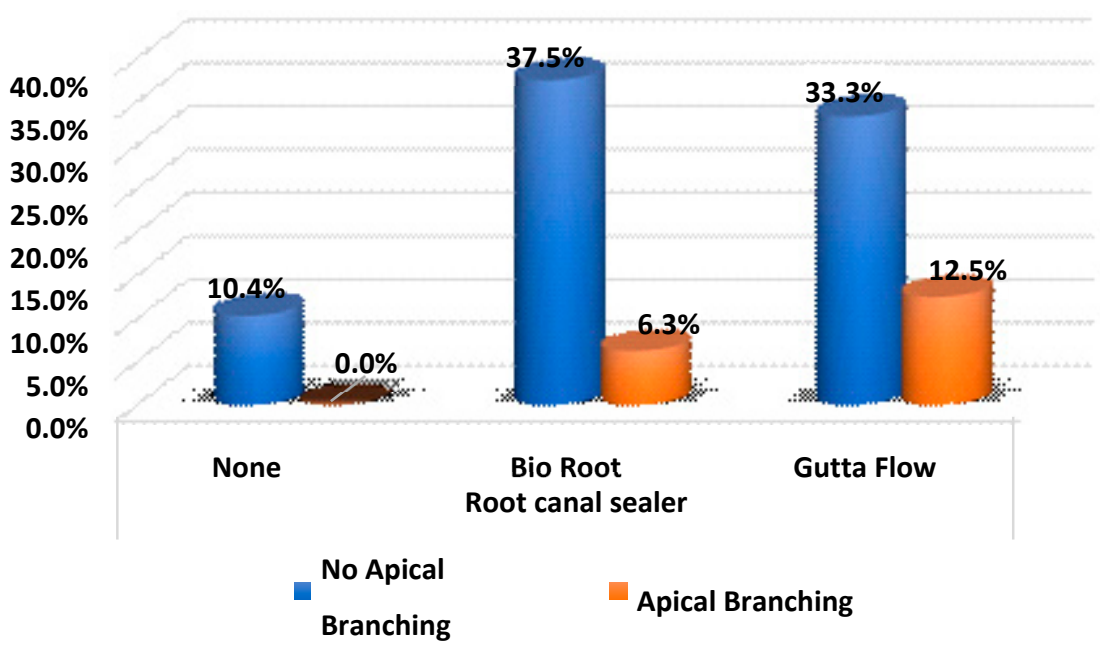

Figure 6. Proportion of apical branches in each root canal sealer group. Bar chart.

\section{Discussion}

We have used a diaphanization technique to evaluate the quantity of SLC filled with two root canal sealers with continuous wave. There are numerous clearing techniques, but the one proposed by Robertson and Leeb [31] is still valid today because of the speed and ease of carrying it out. The clearing technique is a simple method that allows the internal anatomy of the teeth to be observed in three dimensions without requiring specialized tools. Historically, it has been used in combination with Chinese inkjet to observe the natural anatomy of the lateral canal system $[5,31,36]$. It was widely used in studies on simulated lateral canals (SLC) $[28,34,37,38]$, or natural ones [25,39]. Other authors to study SLC base their work on augmented radiographs such as Barbizam et al. [40], or they perform cross sections that must be very precise in the axis of the lateral canals, before submerging the sections in resin before their observation, such as Carvalho-Sousa et al. [41]. It can be combined with the observation of microfiltration after filling the teeth, such as Almeida et al. [37].

Despite having other study techniques, such as micro-CT and FEA, diaphanization presents the possibility of creating SLC. The way to create simulated lateral canals (SLC) differs greatly between authors. Fernández et al. prepare the lateral canals in the teeth after cutting the crowns, because they are not decalcified and, due to their normal rigidity, they can be radiographically verified with a \#08 K-file inserted in the lateral canal that communicates with the principal canal [28]. Carvalho-Sousa et al. prepare the lateral canals with a \# 15 rotary file [41]. Almeida et al. reported that they create the SLC with cylindrical burs of $0.1 \mathrm{~mm}$ diameter at a machining center [37]. Barbizam et al. [40] used a rotary file \#15 adapted to a low-speed hand piece. Venturi et al. intend to standardize a new protocol to create SLC with a 60-micrometer diameter, they do so with a \#06 K-file, from which they have cut the apical 5- or 8-mm decalcified teeth. They then leave the files on the 
teeth during their hardening in methyl salicylate [38,42]. They do not explain why, but we assume it was so that as the teeth harden and shrink during the clearing process, the SLC are not obliterated. Then they seal, allowing them to check the patency of the SLC and its communication with the main canal. Sant'Anna Junior et al. [34] used the same method as this work regarding the creation of lateral canals: after the preparation of the teeth, they are decalcified until reaching a rubbery texture. They insert \#8 and $10 \mathrm{~K}$-files into the lingual and buccal surfaces to create the lateral canals. The differences in the heights of the lateral canals are 2.5 and $8 \mathrm{~mm}$ of the working length like Sant'Anna Junior et al.; in this study, lateral canals were created in the teeth once they had been decalcified, with a \#10 K-file. It is clear to us that the manner and type of file used to create simulated lateral canals (SLC) influences the success of the sealing. That makes comparisons between studies difficult because few studies simulate the proper size of a lateral canal. Most studies make SLC wider [38]. In fact, regarding Venturi et al. [38], the prevailing shape of a natural lateral canal (all types of teeth) is cylindrical, with a diameter of less than $100 \mu \mathrm{m}$. Most of the lateral apical canals reveal diameters of less than $50 \mu \mathrm{m}$, and some between 50 and $100 \mu \mathrm{m}$. Similar diameters were also seen in the middle and coronal third, even if larger sizes were sometimes found.

In the present study, BioRoot ${ }^{\circledR}$ RCS (bioceramic sealer) and GuttaFlow ${ }^{\circledR}$ bioseal (cement based on silicone, gutta-percha particles and bioceramics) have been compared. Statistically significant differences between root canal sealers have been reported. The control group was filled without root canal sealer to verify that the SLC sealing technique was valid. We know that is not the correct way to seal, since cement is always used, but we understood that this way we could know if the clearing technique, the creation of SLC, and subsequent sealing occurred. The control group did not take part in the statistical comparisons.

BioRoot ${ }^{\circledR}$ RCS has allowed more grade 2 fillings (33.3\%) in $3 \mathrm{~mm}$ SLC than GuttaFlow ${ }^{\circledR}$ bioseal (4.5\%). At $10 \mathrm{~mm}$, BioRoot ${ }^{\circledR}$ RCS has allowed more grade 2 fillings $(23.8 \%)$ in SLC than GuttaFlow ${ }^{\circledR}$ bioseal $(0 \%)$. On the other hand, GuttaFlow ${ }^{\circledR}$ bioseal has allowed more grade 3 fillings (27.3\%) in SLC at $6 \mathrm{~mm}$ than BioRoot ${ }^{\mathrm{TM}} \mathrm{RCS}(4.8 \%)$. Among the properties of a root canal sealer, fluidity is an essential property as it allows the filling of hard-to-reach areas such as narrow dentin irregularities, isthmus, accessory canals, and gaps [14]. Flow values for BioRoot ${ }^{\circledR}$ RCS have not been found. However, Tanomaru et al. compared the physicochemical and volumetric properties of AH Plus ${ }^{\circledR}$ (epoxy resin-based cement that has been used as Gold Standard in evaluations root canal sealer), Total Fill ${ }^{\circledR}$ BC Sealer (FKG, bioceramic cement), and GuttaFlow ${ }^{\circledR}$ bioseal; they performed a flow test according to ISO 6876, and for GuttaFlow ${ }^{\circledR}$ bioseal it had significantly lower flow values compared to the other sealants [9]. That could explain that in the coronal third at $10 \mathrm{~mm}$ from the apex, BioRoot $^{\circledR}$ RCS obtained a higher proportion than GuttaFlow ${ }^{\circledR}$ bioseal and was statistically significant ( $p$-value < 0.05) (Figure 4). In addition, the heat instantly set GuttaFlow ${ }^{\circledR}$ bioseal placed in the canal. However, more research is needed on the properties of these cements to be able to explain the results.

Almeida et al. reported there was no difference between the filled thirds [37]. Fernández et al. reported $49.1 \%$ of canals with acceptable filling [28]. In this study, global acceptable filling was of $25 \%$. An acceptable filling (grades 2 to 4 ) was greater in the middle third than in the apical and coronal thirds and was statistically significant, then apical third $(3 \mathrm{~mm})$, and, finally, coronal third $(10 \mathrm{~mm})$. The difference between apical and coronal thirds could be significant. These results correspond to the results obtained in other studies regarding the apical third [28,38-40]. Venturi et al. [38,39] agree that the SLC of the apical third are the most difficult to fill, like Barbizam et al. [40], who obtained a higher percentage of unobstructed or partially filled SLC in the apical third. This is clinically important because the frequency of lateral canals was greatest in the apical third. Venturi et al. [38] founded in maxillary molars natural lateral canals in $65.5 \%$ of the specimens, most of them in the apical third (66.8\%). 
Fernández et al. [28] reported that the percentage of SLC with acceptable filling was significantly higher in the apical third, followed by the middle third and the coronal third, but the differences were not significant between the middle third and the coronal third. According to Carvalho-Sousa et al. [41] the apical third had less filling, followed by the middle third, followed by the coronal third with greater filling, but this was not significant.

The method of the present study included the use of sonic activation and EDTA prior to the obturation to promote better penetration of the filling material into the SLC. The fact of having obtained a worse filling in the coronal third can be attributed to the amount of cement applied, which was less in the coronal third and an improved irrigation in the apical third, thanks to the use of sonic activation. Extrusion of root canal sealer is also a problem in obturation, but we had no differences between cements studied.

Based on the findings of this study and others, it should be highlighted that no association of technique and sealers studied has achieved total root canal system filling. Bioceramic sealers are promising materials, based on their properties, for improving the sealing of SLC and the long-term success of endodontic therapy.

\section{Conclusions}

Within the limitations of the present study, BioRoot ${ }^{\circledR}$ RCS has obtained better sealings in 3 and $10 \mathrm{~mm}$ than GuttaFlow ${ }^{\circledR}$ bioseal. GuttaFlow ${ }^{\circledR}$ bioseal has allowed better fillings in $6 \mathrm{~mm}$. The extrusion ratio and the proportion of apical branches revealed were similar.

The highest proportion of acceptably filled SLC were found in the middle third, followed by the apical third, and finally by the coronal third. The number of cases with unacceptable filling were significantly higher than acceptable at all levels.

Author Contributions: Conceptualization, J.M.-Á., J.T.S. and C.R.-R.; methodology, J.M.-Á., J.T.S. and C.R.-R.; software, J.T.S.; validation, J.M.-Á., J.T.S. and C.R.-R.; formal analysis, J.M.-Á., J.T.S. and C.R.-R.; investigation, J.T.S.; resources, M.Z.-G.; data curation, J.M.-Á. and J.T.S.; writing-original draft preparation, J.M.-Á.; writing—review and editing, J.M.-Á.; visualization, M.Z.-G. All authors have read and agreed to the published version of the manuscript.

Funding: This research received no external funding.

Institutional Review Board Statement: This study was approved by the Research Ethics Committee of Alfonso X El Sabio University (Process No 08/2019).

Informed Consent Statement: The patients gave their informed consent to submit their teeth to the study.

Data Availability Statement: The datasets used and/or analyzed during the current study are available from the corresponding author on reasonable request.

Conflicts of Interest: The authors declare no conflict of interest.

\section{References}

1. Schilder, H. Filling root canals in three dimensions. J. Endod. 2006, 32, 281-290. [CrossRef]

2. Weine, F.S. The enigma of the lateral canal. Dent. Clin. N. Am. 1984, 28, 833-852. [PubMed]

3. Raja Sunitha, V.; Emmadi, P.; Namasivayam, A.; Thyegarajan, R.; Rajaraman, V. The periodontal-endodontic continuum: A review. J. Conserv. Dent. 2008, 11, 54-62. [CrossRef]

4. Cutright, D.E.; Bhaskar, S.N. Pulpal vasculature as demonstrated by a new method. Oral Surg. Oral Med. Oral Pathol. 1969, 27, 678-683. [CrossRef]

5. De Deus, Q.D. Frequency, location, and direction of the lateral, secondary, and accessory canals. J. Endod. 1975, 1, 361-366. [CrossRef]

6. ElAyouti, A.; Achleithner, C.; Löst, C.; Weiger, R. Homogeneity and Adaptation of a New Gutta-Percha Paste to Root Canal Walls. J. Endod. 2005, 31, 687-690. [CrossRef] [PubMed]

7. Akcay, M.; Arslan, H.; Durmus, N.; Mese, M.; Capar, I.D. Dentinal tubule penetration of AH Plus, iRoot SP, MTA fillapex, and guttaflow bioseal root canal sealers after different final irrigation procedures: A confocal microscopic study. Lasers Surg. Med. 2016, 48, 70-76. [CrossRef] [PubMed] 
8. Collado-González, M.; Tomás-Catalá, C.J.; Onate-Sánchez, R.E.; Moraleda, J.M.; Rodríguez-Lozano, F.J. Cytotoxicity of GutaFlow Bioseal, GuttaFlow2, MTA Fillapex, and AH Plus on Human Periodontal Ligament Stem Cells. J. Endod. 2017, 43, 816-822. [CrossRef] [PubMed]

9. Tanomaru-Filho, M.; Torres, F.F.E.; Chavez-Andrade, G.M.; de Almeida, M.; Navarro, L.G.; Steier, L.; Guerreiro-Tanomaru, J.M. Physicochemical Properties and Volumetric Change of Silicone/Bioactive Glass and Calcium Silicate-based Endodontic Sealers. J. Endod. 2017, 43, 2097-2101. [CrossRef] [PubMed]

10. Gandolfi, M.G.; Siboni, F.; Prati, C. Properties of a novel polysiloxane-guttapercha calcium silicate-bioglass-containing root canal sealer. Dent. Mater. 2016, 32, e113-e126. [CrossRef]

11. Zhang, H.; Shen, Y.; Ruse, N.D.; Haapasalo, M. Antibacterial Activity of Endodontic Sealers by Modified Direct Contact Test Against Enterococcus faecalis. J. Endod. 2009, 35, 1051-1055. [CrossRef] [PubMed]

12. Zhang, W.; Li, Z.; Peng, B. Effects of iRoot SP on Mineralization-related Genes Expression in MG63 Cells. J. Endod. 2010, 36, 1978-1982. [CrossRef] [PubMed]

13. Zhang, W.; Li, Z.; Peng, B. Ex vivo cytotoxicity of a new calcium silicate-based canal filling material. Int. Endod. J. 2010, 43, 769-774. [CrossRef] [PubMed]

14. Candeiro, G.T.; Correia, F.C.; Duarte, M.A.H.; Ribeiro-Siqueira, D.C.; Gavini, G. Evaluation of Radiopacity, pH, Release of Calcium Ions, and Flow of a Bioceramic Root Canal Sealer. J. Endod. 2012, 38, 842-845. [CrossRef] [PubMed]

15. Camps, J.; Jeanneau, C.; El Ayachi, I.; Laurent, P.; About, I. Bioactivity of a Calcium Silicate-based Endodontic Cement (BioRoot RCS): Interactions with Human Periodontal Ligament Cells In Vitro. J. Endod. 2015, 41, 1469-1473. [CrossRef]

16. Dimitrova-Nakov, S.; Uzunoglu, E.; Ardila-Osorio, H.; Baudry, A.; Richard, G.; Kellermann, O.; Goldberg, M. In vitro bioactivity of Bioroot $^{\mathrm{TM}}$ RCS, via A4 mouse pulpal stem cells. Dent. Mater. 2015, 31, 1290-1297. [CrossRef] [PubMed]

17. Eldeniz, A.U.; Shehata, M.; Hogg, C.; Reichl, F.X. DNA double-strand breaks caused by new and contemporary endodontic sealers. Int. Endod. J. 2016, 49, 1141-1151. [CrossRef] [PubMed]

18. Siboni, F.; Taddei, P.; Zamparini, F.; Prati, C.; Gandolfi, M.G. Properties of BioRoot RCS, a tricalcium silicate endodontic sealer modified with povidone and polycarboxylate. Int. Endod. J. 2017, 50, e120-e136. [CrossRef]

19. Arias-Moliz, M.T.; Camilleri, J. The effect of the final irrigant on the antimicrobial activity of root canal sealers. J. Dent. 2016, 52, 30-36. [CrossRef]

20. Can, E.D.B.; Keleş, A.; Aslan, B. Evaluation of the root filling quality of three root canal filling systems with micro-CT. Int. Endod. J. 2016, 50, 499-505. [CrossRef]

21. Naseri, M.; Kangarlou, A.; Khavid, A.; Goodini, M. Evaluation of the quality of four root canal obturation techniques using micro-computed tomography. Iran. Endod. J. 2013, 8, 89-93.

22. Keleş, A.; Alcin, H.; Kamalak, A.; Versiani, M.A. Micro-CT evaluation of root filling quality in oval-shaped canals. Int. Endod. J. 2014, 47, 1177-1184. [CrossRef]

23. Somma, F.; Cretella, G.; Carotenuto, M.; Pecci, R.; Bedini, R.; De Biasi, M.; Angerame, D. Quality of thermoplasticized and single point root fillings assessed by micro-computed tomography. Int. Endod. J. 2011, 44, 362-369. [CrossRef] [PubMed]

24. Celikten, B.; Uzuntas, C.F.; Orhan, A.I.; Tufenkci, P.; Misirli, M.; Demiralp, K.O.; Orhan, K. Micro-CT assessment of the sealing ability of three root canal filling techniques. J. Oral Sci. 2015, 57, 361-366. [CrossRef] [PubMed]

25. Venturi, M.; Prati, C.; Capelli, G.; Falconi, M.; Breschi, L. A preliminary analysis of the morphology of lateral canals after root canal filling using a tooth-clearing technique. Int. Endod. J. 2003, 36, 54-63. [CrossRef]

26. Roizenblit, R.N.; Soares, F.O.; Lopes, R.T.; Dos Santos, B.C.; Gusman, H. Root canal filling quality of mandibular molars with EndoSequence BC and AH Plus sealers: A micro-CT study. Aust. Endod. J. 2020, 46, 82-87. [CrossRef]

27. Cen, R.; Wang, R.; Cheung, G.S.P. Periodontal Blood Flow Protects the Alveolar Bone from Thermal Injury during Thermoplasticized Obturation: A Finite Element Analysis Study. J. Endod. 2018, 44, 139-144. [CrossRef] [PubMed]

28. Fernandez, R.; Restrepo, J.S.; Aristizabal, D.C.; Alvarez, L.G. Evaluation of the filling ability of artificial lateral canals using cal-cium silicate-based and epoxy resin-based endodontic sealers and two gutta-percha filling techniques. Int. Endod. J. 2016, 49, 365-373. [CrossRef]

29. Boutsioukis, C.; Lambrianidis, T.; Verhaagen, B.; Versluis, M.; Kastrinakis, E.; Wesselink, P.R.; Van Der Sluis, L.W.M. The Effect of Needle-insertion Depth on the Irrigant Flow in the Root Canal: Evaluation Using an Unsteady Computational Fluid Dynamics Model. J. Endod. 2010, 36, 1664-1668. [CrossRef]

30. Haapasalo, M.; Shen, Y.; Wang, Z.; Gao, Y. Irrigation in endodontics. Br. Dent. J. 2014, 216, 299-303. [CrossRef]

31. Robertson, D.; Leeb, I.J.; McKee, M.; Brewer, E. A clearing technique for the study of root canal systems. J. Endod. 1980, 6, 421-424. [CrossRef]

32. Barrington, C. Clearing a Tooth to Expose Internal Anatomy. Endodontic Practice US. 2015. Available online: https:// endopracticeus.com/clearing-a-tooth-to-expose-internal-anatomy/ (accessed on 3 April 2021).

33. Saleh, I.M.; Ruyter, I.E.; Haapasalo, M.; Orstavik, D. Survival of Enterococcus faecalis in infected dentinal tubules after root canal filling with different root canal sealers in vitro. Int. Endod. J. 2004, 37, 193-198. [CrossRef]

34. Sant'Anna-Junior, A.; Guerreiro-Tanomaru, J.M.; Martelo, R.B.; Da Silva, G.F.; Tanomaru-Filho, M. Filling of simulated lateral canals with gutta-percha or thermoplastic polymer by warm vertical compaction. Braz. Oral Res. 2015, 29, 56. [CrossRef] [PubMed] 
35. Yilmaz, Z.; Tuncel, B.; Ozdemir, H.O.; Serper, A. Microleakage evaluation of roots filled with different obturation techniques and sealers. Oral Surg. Oral Med. Oral Pathol. Oral Radiol. Endodontol. 2009, 108, 124-128. [CrossRef]

36. Vertucci, F.J. Root canal anatomy of the human permanent teeth. Oral Surg. Oral Med. Oral Pathol. 1984, 58, 589-599. [CrossRef]

37. de Almeida, J.F.A.; Gomes, B.P.; Ferraz, C.C.R.; Souza-Filho, F.J.; Zaia, A.A. Filling of artificial lateral canals and microleakage and flow of five endodontic sealers. Int. Endod. J. 2007, 40, 692-699. [CrossRef]

38. Venturi, M.; Di Lenarda, R.; Prati, C.; Breschi, L. An In Vitro Model to Investigate Filling of Lateral Canals. J. Endod. 2005, 31, 877-881. [CrossRef]

39. Venturi, M. An Ex Vivo Evaluation of a Gutta-Percha Filling Technique When Used with Two Endodontic Sealers: Analysis of the Filling of Main and Lateral Canals. J. Endod. 2008, 34, 1105-1110. [CrossRef]

40. Barbizam, J.V.B.; Souza, M.; Cecchin, D.; Dabbel, J. Effectiveness of a silicon-based root canal sealer for filling of simulated lateral canals. Braz. Dent. J. 2007, 18, 20-23. [CrossRef]

41. Carvalho-Sousa, B.; Almeida-Gomes, F.; Carvalho, P.R.B.; Cláudio, M.F.; Gurgel-Filho, E.D.; Albuquerque, D.S. Filling lateral canals: Evaluation of different filling techniques. Eur. J. Dent. 2010, 4, 251-256. [CrossRef]

42. Venturi, M.; Di Lenarda, R.; Breschi, L. An ex vivo comparison of three different gutta-percha cones when compacted at different temperatures: Rheological considerations in relation to the filling of lateral canals. Int. Endod. J. 2006, 39, 648-656. [CrossRef] [PubMed] 